\title{
Editorial
}

\section{The paradox of overspecialization: can't see the forest for the trees}

\author{
Nathan Moreau* \\ Department of Oral Medicine and Oral Surgery, Bretonneau Hospital, AP-HP, Paris, France
}

"An expert is a person who has made all the mistakes that can be made in a very narrow field."

Niels Bohr (1885-1962)

The exponential growth in medical knowledge -16 millions citations in the MEDLINE ${ }^{\oplus}$ database in 2007 and more than 30 millions in 2020-along with technological advances in both diagnostics and therapeutics have been essential drivers of medical specialization throughout the past decades [1]. Specialization is a logical consequence of the evolution of Medicine (and Surgery), but it is probable that overspecialization may carry significant drawbacks $[2,3]$. In surgery for instance, early (and too important) specialization may lead to poor surgical training and the inability to change to a new subspecialty or to address more "general" surgical problems. Furthermore, overspecialization can become an invitation to medical overconsumption, considering that there is always room for another (more specialized) medical opinion [2].

The field of Dental Medicine has not been forgotten in the era of medical specialization and a number of practitioners opt for a practice limited to a specific subspecialty (endodontics, periodontics, prosthodontics, pedodontics, aesthetic dentistry, etc.). Whereas having the possibility of specialist consult and management is obviously very fruitful for patients, one can wonder whether too much specialization can lead to poor patient outcome when the clinical problem falls out of both the generalist's and the specialist's scopes of expertise.

Furthermore, overspecialization can lead to an interesting paradox, namely the inability to diagnose and treat a condition that clearly falls within the specialist's expected scope of practice and expertise because of a too-focused (and thus too-limited) practice. It is as if the overspecialist can't see the forest for the trees.
There are numerous examples from the various subspecialties of Dental Medicine that can be drawn to illustrate such paradox $[4,5]$, be it a periodontist unfamiliar with gingival lichen planus presenting as refractory bacterial gingivitis or an endodontist unfamiliar with the radiographic presentation of periapical osseous dysplasia, just to name two. Illustrative examples from the author's personal practice can be found in Table I.

As clinicians and teachers, we must ask ourselves: How can we mitigate such an unfortunate paradox?

Two - simple but potent-ideas come to mind:

- Encourage versatility: A popular saying states that "The specialist is a man who knows more and more about less and less, whereas the generalist is a man who knows less and less about more and more". If such a saying has some veracity, a middle ground could be found in the form of a "versatilist" i.e. a man who knows more and more about more and more (although not knowing everything about everything) as illustrated in Figure 1.

- Promote and practice collaborative interspecialty training: Each subspecialty has its own specific expertise to offer to other subspecialties and to the general dental practice. This can present as continuing professional development courses for practitioners (examples of which can be found in Table II) or specific lectures, articles or books focusing on improving a specific part of the specialist's existent field of expertise (e.g. improving the training of periodontists in gingival "dermatology" [6]).

All in all, although having a specialized practice is a rewarding professional endeavor that can only be encouraged, one should always keep in mind and try to mitigate the risk and paradox of overspecialization.

\footnotetext{
*Correspondence: nathan.moreau@u-paris.fr
} 
Table I. Non-exhaustive examples of misdiagnosed pathologies that fell within the specialist's expected field of expertise.

\begin{tabular}{|c|c|c|c|c|}
\hline Specialist & Pathology & $\begin{array}{c}\text { Clinical } \\
\text { presentation }\end{array}$ & $\begin{array}{c}\text { Consequence(s) of } \\
\text { misdiagnosis }\end{array}$ & Reference \\
\hline \multirow[t]{2}{*}{ Endodontist } & $\begin{array}{l}\text { Painful Post- } \\
\text { Traumatic Trigeminal } \\
\text { Neuropathy }\end{array}$ & $\begin{array}{l}\text { Chronic odontalgia } \\
\text { Pain upon axial } \\
\text { percussion } \\
\text { Pain upon palpation of } \\
\text { the periapical region }\end{array}$ & $\begin{array}{l}\text { Unnecessary iatrogenic } \\
\text { surgery (endodontic } \\
\text { retreatment, tooth } \\
\text { avulsion, apical surgery) }\end{array}$ & $\begin{array}{l}\text { Moreau \& Boucher } \\
2020 \text { [4] }\end{array}$ \\
\hline & $\begin{array}{l}\text { Periapical osseous } \\
\text { dysplasia (OD) }\end{array}$ & Periapical radiolucency & $\begin{array}{l}\text { Unnecessary endodontic } \\
\text { treatment and possible } \\
\text { superinfection of the } \\
\text { avascular OD lesions }\end{array}$ & Daviet et al. 2017 [5] \\
\hline \multirow[t]{2}{*}{ Periodontist } & Gingival lichen planus & $\begin{array}{l}\text { Refractory bacterial } \\
\text { gingivitis }\end{array}$ & $\begin{array}{l}\text { Disease progression and } \\
\text { persistent oral pain }\end{array}$ & $\begin{array}{l}\text { Moreau } 2013 \\
\text { (unpublished residency } \\
\text { dissertation) }\end{array}$ \\
\hline & $\begin{array}{l}\text { Gingival squamous } \\
\text { cell carcinoma }\end{array}$ & $\begin{array}{l}\text { Refractory bacterial } \\
\text { gingivitis or periodontitis }\end{array}$ & $\begin{array}{l}\text { Cancer progression and } \\
\text { worsened outcome }\end{array}$ & Unpublished case \\
\hline \multirow[t]{2}{*}{ Oral surgeon } & $\begin{array}{l}\text { Bruxism-related } \\
\text { masseter myalgias }\end{array}$ & $\begin{array}{l}\text { Mandibular third molar } \\
\text { pericoronaritis }\end{array}$ & $\begin{array}{l}\text { Unnecessary mandibular } \\
\text { third molar avulsion }\end{array}$ & Unpublished case \\
\hline & $\begin{array}{l}\text { Mandibular } \\
\text { actinomycosis }\end{array}$ & Non-healing socket & $\begin{array}{l}\text { Post-curettage injury of } \\
\text { the inferior alveolar nerve } \\
\text { Increased bone loss }\end{array}$ & Unpublished case \\
\hline
\end{tabular}

Table II. Suggested themes for Continuing Professional Development courses in several subspecialties.

\begin{tabular}{|l|l|}
\hline Specialty & \multicolumn{2}{|l|}{ Suggested training themes } \\
\hline Endodontics & $\begin{array}{l}\text { Neuropathic odontalgias (painful post-traumatic trigeminal neuropathy) } \\
\text { Non-odontogenic tooth pain (e.g. referred pain from myalgias, headache, } \\
\text { sinusitis...) } \\
\text { Differential diagnoses of periapical radiolucencies (osseous dysplasia, } \\
\text { actinomycosis, lymphoma...) }\end{array}$ \\
\hline Periodontics & $\begin{array}{l}\text { Non-bacterial gingival diseases (auto-immune diseases, bullous diseases...) } \\
\text { Malignant diseases affecting the gingiva (squamous cell carcinoma, gingival } \\
\text { hyperplasia secondary to leukemia....) }\end{array}$ \\
\hline Oral surgery & $\begin{array}{l}\text { Post-implant neuropathic pain } \\
\text { Differential diagnosis of chronic orofacial pain conditions (especially cancer } \\
\text { and cardiac referred pain) } \\
\text { Vascular pain (cervical artery dissection) }\end{array}$ \\
\hline Pedodontics & $\begin{array}{l}\text { Leukemic gingival hyperplasia } \\
\text { Oral enanthemas (scarlet fever, Kawazaki disease...) } \\
\text { Genetic diseases (hemophilia, cyclic neutropenia, ...) }\end{array}$ \\
\hline
\end{tabular}




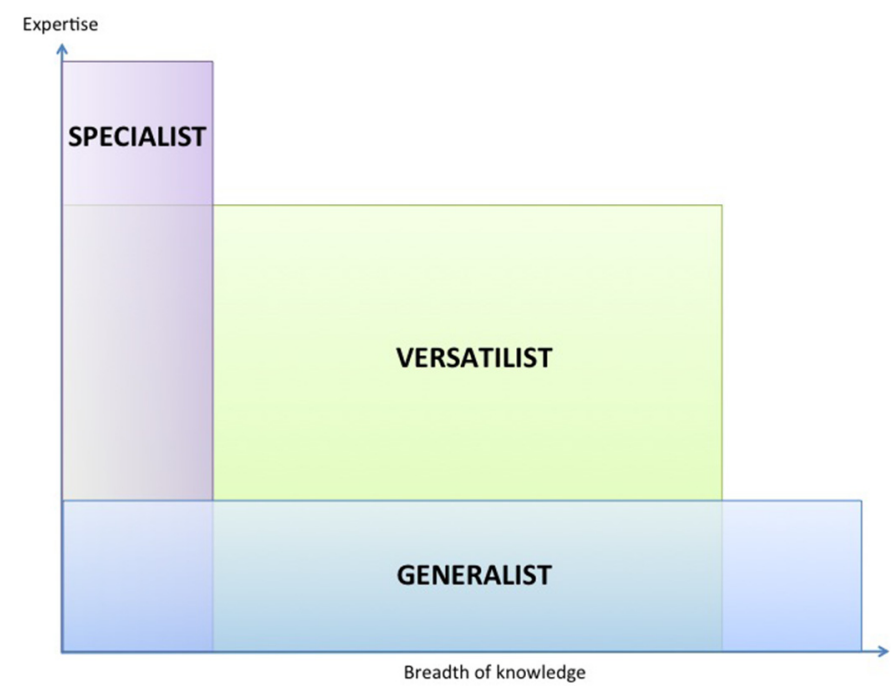

Fig. 1. Graphical illustration of the differences in expertise and breadth of knowledge between a generalist (e.g. general dental practitioner), a versatilist (e.g. oral surgeon) and a specialist (e.g. implantologist).

\section{Conflict of interest}

Author declared no conflict of interests.

\section{References}

1. Forest CB. A typology of specialists's clinical roles. Arch Intern Med 2009;169:1062-1068.

2. Villet R. Overspecialization in surgery. Chirurgie 1991;117: 208-211.

3. Loefler IJ. The drawbacks of overspecialisation. J R Coll Surg Edinb 1999;44:11-12.

4. Moreau N, Boucher Y. Encyclopédie Médico-Chirurgicale Médecine Buccale 2020 [Article 28-290-C-10].

5. Daviet V, Ejeil AL, Gossiome C, Salmon B, Moreau N. Differentiating early stage florid osseous dysplasia from periapical lesions: a radiological-based diagnostic algorithm. BMC Oral Health 2017;17:161.

6. Dridi SM, Ejeil AL, Gaultier F, Meyer J. La gencive pathologique - de l'enfant à l'adulte. Diagnostics et thérapeutiques. Paris: Espace ID 2013 